\title{
МОЛКОТ НА ЖЕНИТЕ ВО ВИЗАНТИЈА ПОМЕЃУ КАНОНИТЕ И РЕАЛНОСТА
}

\section{Кратка содржина}

Предмет на нашето истражување е молкот на жените во средниот век, со посебен акцент на молкот на жените во Византија, или поточно колку во реалноста се придржувале до канонската одредба за тоа дека жената треба да молчи пред мажот во чрква?

Да бидеш роден како маж или жена во кое било општество не претставува само обичен биолошки факт. Тоа е биолошки факт со соиијални импликаиии. Жените сочинуваат посебна сочијална група, а карактерот на таа група, ито историчарите долго време го занемарувале, нема ништо заедничко со женската „природа“. Проблемот лежи во самата природа на општеството и сфаќањето за жената, за која законските одредби и историските извори зборуваат од посебен аспект-машкиот поглед на свет. Мажите имале законска самостојност и право јавно да зборуваат, што на жените им било или забрането или допуштено со негодување. Мажите ја поседувале моќта, па според тоа, нашите извори главно зборуваат за нив. Особено е тешко да се нарре под повриината на средниот век за да се осознае жсивотот на поскромните членови на општеството. Токму затоа, нашето внимание е насочено кон податочите за жените од владетелските фамилии, императорките, колку за нив важеле одредбите за молчење и како некои од нив се впуштале во дискусии по одредени верски прашањ а, а нивните мислења довеле до значајни одлуки кои ито имале битно влијание на настаните во Византија. Сите Византијџи кои сочувале податочи за својата ицвилизачија (историчари, правници или составувачи на житија) биле мажи и нивните списи се посветени на дејноста на нивните машки колеги, тој факт го отежнува нашето истражување и затоа ќе се повикаме на законските одредби од византиското законодавство.

Клучни зборови: ЖЕНИ; ЗАКОНИ; КАНОНИ; ИМПЕРАТОРКИ; ЦРКОВНИ РАСПРАВИ; МОЛЧЕњЕ

\section{ЕКСПОЗЕ:}

Познато е дека Византија е првата држава во која христијанството било признато за рамноправна религија уште во 313 година со т.н. Милански едикт, а подоцна и за државна религија. Византија е првата држава во која започнал да се изградува христијанскиот поглед на свет и во која се градел христијанскиот модел на живеење, усогласен со христијанските норми и канони. 
Токму врз тој христијански модел се граделе и односите меѓу родовите, односите маж-жена и се утврдувале местото и улогата на жената во општеството. Од Византија овој модел бил прифатен во сите држави кои што го примиле христијанството и потоа го развивале тој модел според своите традиции и потреби.

Христијанското учење влијаело и за формирањето на основните претстави за жените, па оттаму и за тоа кога, каде и како треба да зборуваат жените.

Што се однесува до зборовите и молчењето на жените, признаен авторитет бил св. Павле, кој ги сметал жените за инфериорни во однос на мажите и им забранувал да подучуваат (Тим. 1.2:12) и да се обраќаат на собори, дозволувајќи им, доколку сакале да добијат некоја специфична информација, да си ги прашаат сопрузите дома (Кор 1.14:34-35) Во неговото послание до Коринтјаните апостол Павле вели: „жените ваши по црквите да молчат: ним не им е позволено да зборуваат, туку да се покоруваат, како што вели Законот“ (Тит. 2, 5; 1. Тим 2, 12; Кор. $3,18$; Ефес. 5,$22 ; 1$ Moj. 3,16$)^{1}$. Понатаму додава: „Ако пак сакаат да научат нешто, нека ги прашаат мажите свои дома, зашто срамно е жена во црква да зборува“.2 Овие библиски пасуси, кои со векови биле коментирани од голем број учени, биле камен темелници на старателството препорачано од проповедниците и моралистите. Првата задача била да се протераат зборовите на жените од јавниот форум во приватноста. Канонското право докажувало дека жените се неподобни за подучување и проповедање.

Колку тоа канонско право било спроведувано во реалноста во Византија, и дали жените навистина молчеле, ќе се обидеме да покажеме на примери од секојдневниот живот, во кој што живот, жените имале активна улога.

Веднаш на почетокот мораме да истакнеме дека византиското граѓанско право одразено во законите на Јустинијан I, Лав III, Василиј I и Лав VI Мудри им даваат право на жените и женските деца да наследуваат имот од своите мажи и татковци, да раководат со свои работилници, да имаат трговски претпријатија, да го водат семејството, да ги подучуваат децата и сл. Од друга страна, жената се осамостојувала откако ќе умрел мажот и таa ќе останела вдовица, во тој случај таа го водела наследениот имот, а доколку била жена на император можела да управува и со државата како регентка на малолетните синови, а во таков случај таа имала право слободно да ги истакнува своите мисли и идеи, па дури и да свикува и раководи со црковни и Вселенски собори.

Од многубројните примери во Византија, ќе се задржиме на неколку значајни жени за судбината на државата.

Нормално, започнуваме со св. Елена, мајката на првиот христијански владетел во Византија - Константин I Велики. Елена според преданието го открила Чесниот крст. Тука се среќаваме со ноќни мотиви. На Елена на сон ѝ се прикажало дека крстот се наоѓ во Ерусалим под некој храм на демони. Тогаш царицата заминала за Ерусалим и веднаш потоа Бог му го покажал на епископот местото на

\footnotetext{
${ }^{1}$ Свето Писмо (Библија). Скопје 1990, 221.

${ }^{2}$ Исто, 221.
} 
кое бил подигнат храм на демоните и статуа. Тогаш царицата ја употребила својата власт, собрала многу мајстори и работници и наредила храмот да се разруши до темел. Кога тоа било направено, се појавил гробот Божји и недалеку оттаму три крста закопани во земја. Кога внимателно ја пребарале околината, пронашле и клинци. Царицата ја обзела тага, бидејќи не знаела кој е вистинскиот крст на кој бил распнат Исус. Нејзината дилема ја разрешил епископот со верата. Тој на една болна жена од некоја угледна куќа, која што сите ја напуштиле и која тогаш била на умирање, им ги принесувал крстовите еден по еден и така го пронашол вистинскиот. Кога сенката на Спасоносниот крст ја допрела болната, таа во истиот момент станала и гласно го славела Бога. Царицата тогаш со голема радост и со страв го подигнала крстот, па еден дел со клиновите го однела кај својот син, а потоа направила сребрен кивориј и остатокот од крстот го предала на епископот на градот за да го паметат сите поколенија. Издала наредба да се изгради црква на живототворниот гроб на света Голгота, во Витлеем, каде што Господ примил раѓање по тело и на Маслиновата гора, каде што Господ ги благословил своите ученици и потоа се вознел на небото. Откако направила уште многу добри дела се вратила кај синот ${ }^{3}$.

Од наведеното јасно се гледа дека св. Елена наредува да се сруши храмот, дава наредба да се изгради црква, а тоа значи дека таа не молчела, туку им наредува на мајсторите, кои што се претежно мажи и тие ги слушаат нејзините наредби.

Вториот пример се однесува на Ариадна, вдовицата на императорот Зенон. По смртта на Зенон, вечерта на 9 април 491 година во портиците пред големата сала на дворецот се собирале вишите чиновници, патријархот и членовите на сенатот. Истовремено на хиподромот се собирал народот, првично поделен на партии, си ги заземале местата. Тие биле опкружени од војската, делови од гардата, исто така се подготвувале да земат учество во изборот на новиот император. Се слушнале извици за потребата да се каже името на идниот цар. По совет на чиновниците вдовицата на Зенон - императорката Ариадна, облечена во порфирна облека излегла во придружба на патријархот Ефтимиј, двајца препозити, магистерот на официите и други високи личности. Нејзиното појавување било пресретнато со извиците: „Ариадна августа, твоја е Победата!“, „Православен цар за Вселената! “4. Царицата се обратила кон присутните со говор, во кој што објавила дека веќе дала неопходни наредби на Сенатот (синклитот) и на претставниците на војската. Ним им било кажано да бараат император христијанин, роден Римјанин (по род Римјанин), доблесен и благочестив маж.

Потоа кога вревата се стишила, гласникот на императорката потврдил дека императорката би сакала сите желби и барања да почекаат (да се позабават) и сите учесници треба да мислат исклучиво за доброто на државата. На крајот Ари-

\footnotetext{
${ }^{3}$ PG 87, 4061C-4064A, Спореди и: Жан-Клод Шене, Бернар Флизен, Византија -Историја и чивилизачија. CLIO, Београд 2010, 243.

${ }^{4}$ Острогорски Г., Историја Византије. Београд 1969, стр. 83; Величко А., История Византийских императоров. I том. Москва, 2012, стр. 427; Norič Dž. Dž., Vizantija rani vekovi. Beograd 2009, 166.
} 
адна побарала да не се брза со изборот, за да се даде можност достојно и благочестиво да се изврши погребот на покојниот цар. Од народот повторно се слушнале извици: „Ред и благочестие во градот!, „Многу години, царице!“, „Чувај го, Боже, нејзиниот живот!“”, „Царството е твое, Ариадна, твоја е победата!“.

Царицата се вратила во своите одаи, а останатите чиновници и патријархот не можеле да дојдат до заедничко решение за кандидат. Тогаш препозитот Урбикиј предложил еден прост излез - да се остави изборот на самата царица. По кратко размислување Ариадна го изговорила името на сенаторот Анастасиј, кој што бргу го довеле во дворецот и го внеле во салата на конзисториумот. Следниот ден се извршил погребот на Зенон. После два дена по смртта на Зенон, во Страсниот петок, 11 април 491 година сите чиновници и патријархот Евтимиј се собрале во бела облека и кон нив поздравувајќи ги присутните, дошол Анастасиј ${ }^{5}$. Чиновниците и членовите на сенатот го молеле него да даде заклетва дека ќе управува според честа и нема да прави зла против било кој, и тој ја дал заклетвата. Потоа Анастасиј облечен во императорска облека бил поздравен од војската и издигнат на штит. Пред насобраниот народ Анастасиј одржал говор при што истакнал: „Јасно е дека човечката власт зависи од волјата од Горе. Семилостивата августа Ариадна по сопствено решение, избраните чиновници и Сенатот, во согласност со војската и „светиот“ народ ме принудија мене, против вољата да ја прифатам на себе грижата за Римското царство. Бог нека биде со вас!“6”.

Следниот пример е поврзан со Теодора-жената на Јустинијан I. За разлика од првите две жени, кои што биле вдовици и можеби таквата положба им давала право да зборуваат и да изнесуваат сопствени мислења, Теодора била во брак со Јустинијан иако имала ниско потекло. Поради големата љубов на Јустинијан кон неа, императорот Јустин го повлекол законот кој што забранувал склучување на брак меѓу високо поставени лица (чиновници, аристократи, сенатори и сл.) со актерки (глумици), танчарки и воопшто со лица од ниски социјални групи, за да му удоволи на внукот Јустинијан и му дозволи да се ожени со Теодора ${ }^{7}$.

Во 523 година се случила свадбата, по што Теодора ја добила титулата патриција.

Теодора била роден политичар и прекрасно ги разбирала проблемите на државното управување. Сите летописци едногласно тврдат дека во државните работи Теодора била прв соработник и другар на императорот и имала авторитет скоро исто колку него. Сите свои тајни таа ги делела со мажот. Таа самата велела дека „императорот ништо не решава без совет со неа самата“, и самиот Јустинијан пишува дека: „посоветувајќи се во тој случај уште еднаш со нашата преосвештена и благочестива сопруга, која што Бог нам ни ја дари, ние решивме...“8 ${ }^{8}$. Доколку се

\footnotetext{
${ }^{5}$ Величко А., История Византийских императоров. I том. стр. 427.

${ }^{6}$ Величко А., История Византийских императоров. І том. стр. 428 ; Кулаковский Ю. А., История Византии. Т. 1. Санкт Петербург, 2003, стр. 393, 394, 395.

${ }^{7}$ Величко А., История Византийских императоров, II том, стр. 31.

${ }^{8}$ Успенски Ф. И., История Византийской империи. Т. 1 Москва, 1948, стр. 530.
} 
случело зборувањето на императорот да било спротивно од мислењето на императорката, неретко победувала вољата на жената.

При аудиенцијата гостот исто така паѓал пред нејзините нозе и им ги целувал обувките. Без секаков поговор таа била сметана за фигура еднаква на императорот. Чиновниците и патрициите, војсководачите и војниците се колнеле: „во Семоќниот Бог, Неговиот Единороден Син, Господ наш Исус Христос, и Светиот Дух, светата славна Богородица и Приснодева Марија, четирите Евангелија, светите архангели Михаил и Гаврил, дека добро ќе им служам на благочестивите и светли господари Јустинијан и Теодора, сопругата на неговото императорско величество...“99.

Императорката станала „женски лидер“, секоја жена можела да ѝ се обрати и да ѝ се пожали на својот маж или да бара помош ${ }^{10}$.

Колку биле пресудни советите на Теодора, најдобро може да се согледа од нејзиниот говор одржан пред сенаторите и војсководачите, по повод размислувањата на Јустинијан и неговите советници, да го напуштат Константинопол и да избегаат пред опасноста од бунтовниците во востанието „Ника“. Блиските соработници на Јустинијан го советувале да го напушти Константинопол и да избега во Хераклеја, за оттаму да организира борба за тронот. Тогаш збор зела Теодора, при што меѓу другото рекла: „сметам дека сегашниот момент најмалку ни дозволува да расправаме за тоа дека жената не треба да се истакнува пред мажи или да се перчи тогаш, кога тие се колебаат дали да постапат така или инаку. Тие кои се наоѓаат во опасност треба да ги уредат колку се може подобро моменталните работи. Јас сметам дека бегството како никогаш, така и сега, дури и да носи спас, е неповолно за нас. Секој кој што дошол на белиот свет не може да не умре, а тој кој што еднаш станал император не може да го поднесе изгнанството. Јас не би можела да живеам без оваа багреница (црвена свилена наметка), ниту би останала жива во тој ден кога минувачите не би ме нарекле господарка. Ако императоре, ти сакаш да избегаш, тоа нема да те чини ништо. Ние имаме пари, и море, и кораби, но, внимавај да не би кога се спасиш да претпочиташ да си умрел - наместо да си се спасил. На мене многу ми се допаѓа една стара поговорка, која вели дека: „Најдобар мртовечки покров - е пурпурната императорска облека“"11.

Овој настап на Теодора ги воодушевил присутните и повеќе никој не помислувал на бегство.

Уште повпечатлив пример имаме со императорката Ирина. Таа се појавила на свет 752 година во Атина, потекнувала од сиромашно семејство, но била

${ }^{9}$ Дил Ш., Юстиниян и византийская ијвилизация во VI век. Спб.1909, стр.57; История Византийских императоров, II, 32.

${ }^{10}$ Бейкер Дж., Юстиниян. Великий законодател. Москва 2004. стр. 36-37.

${ }^{11}$ Procopii Caesariensis, De bello Persikum. I. Lipsiae 1906, 24, p.123-134; Подбрани извори за историята на Византия. Под Редакция на Ангелов Д., София, 1956, стр.54; Прокопий Кесарийский, Война с персами. Книга I, гл.XIV, Москва 1993. стр.79; Успенски Ф., Историја византијског чарства. Т.1. Београд 2000, 351; Жан-Клод Шене, Бернар Флизен, Византија -Историја и иивилизачија. Стр.60; Norič Dž. Dž., Vizantija rani vekovi, 180. 
многу убава ${ }^{12}$. Ирина била решителна и смела жена. Стравувајќи за губењето на својот авторитет, таа после смртта на нејзиниот маж не си дозволила никакви вонбрачни врски и си создала друштво од поголем круг на евнуси. Иако била крунисана за императорка, таа по природа сметала дека официјалната власт во Римската империја му припаѓa на нејзиниот малолетен син, како маж, и името на Константин VI стоело во државните документи пред името на мајката ${ }^{13}$.

Ирина припаѓала кон тие моќни фигури, кои што биле способни да го презрат времето, да го променат текот на историските настани, не плашејќи се да понесе одговорност за своите постапки.

Во мај 784 година се разгореле дискусиите за иконите. Ирина се посоветувала со Тарасиј, нејзин личен секретар и оценила дека треба да ја искористи можноста да свика Вселенски Собор, без што никаква реставрација на иконопочитувањето би била невозможна. Заедно со својот секретар, тие ја разиграле комбинацијата, со цел да го подготват општественото мислење кон воспоставување на иконопочитувањето ${ }^{14}$.

Императорката го свикала Синклитот (Сенатот), на кој предложила за Константинополски патријарх да го назначат Тарасиј (784-806), кој што во почетокот не прифаќал, но потоа во договор со Ирина, прифатил. Тарасиј бил световно лице и како мирјанин не бил обврзан да ги прифати одредбите на соборот од 754 година. Императорката пред насобраниот народ го изјавила следното: „Вие браќа, знаете што направил патријархот Павле, ако тој беше жив, тогаш ние не би му допуштиле на него да го остави патријаршискиот престол иако тој примил монашка схима. Но, доколку, како што е угодно на Бога, тој се преставил од животот, тогаш да размислиме за човекот, кој што би можел да нѐ упати нас и да ја управува Божјата Црква со поучувачки слова. Ние него го назначуваме, но тој не слуша, да му дозволиме тој да каже од кои причини не го прифаќа гласот на царицата и целиот народ“15! Во своја одбрана секретарот иे изјавил на царицата дека ќе го прими повикот само во случај ако биде свикан Вселенски Собор. На 26 декември 784 година, Тарасиј станал Константинополски патријарх ${ }^{16}$, а потоа направил соодветни покани за Собор до останатите источни патријарси ${ }^{17}$.

12 Величко А., История Византийских императоров. 3 том, 82;

${ }^{13}$ Nikephoros, ed. De Boor,para. 88; tr. Mango, 163; Judith Herrin, Women in purple. Weidenfeld \& Nicolson, London 2001, 51.

${ }^{14}$ Феофан Византиец, Летопись от Диоклетиана до царей Михаила и сына его Феофилакта, Рязань 2005. стр. 390-392; Величко А., История Византийских императоров, 82; Успенски Ф., Историја византијског изарства. Т. 1, 703.

${ }^{15}$ Феофан Византиец, Летопись от Диоклетиана до ирарей Михаила и сына его Феофилакma, стр. 392; Величко А., История Византийских императоров, 87. Спореди и: Остроумов М. А., Догматическое значение Седьмого Вселенского Сабора. Спб. 1884; Карташов А. В., Васељенски Сабори. Превод и поговор Мира Лалић, Београд 2009. стр. 528.

${ }^{16}$ Карташов А. В., Васељенски Сабори, 528.

${ }^{17}$ Успенски Ф., Историја византијског иарства. Т. 1, 704. 
Царицата се обратила и до папата, при што му напоменала на неговата должност да ги воспостави и утврди традициите во однос на почитувањето на иконите. Таа го молела папата лично да дојде на Соборот, или во краен случај да испрати свои легати. Папата испратил двајца свои легати на Соборот ${ }^{18}$.

За почеток на Соборот бил определен месец август 786 година во Константинопол. На 17 август почнале првите заседанија и биле донесени првите акти. Но, дошло до бунт на војската, војниците влегле и го затвориле Соборот ${ }^{19}$.

Ирина нашла излез од ситуацијата. Ги испратила војските на Исток под изговор за напад од Арабите. Во исто време во Константинопол пристигнале пограничните војски верни на императорката. После една година императорката објавила проглас за повторно свикување на Вселенскиот Собор, но овој пат во Никеја. Првиот дел имал 8 заседанија и се одржал на 24 септември 787 година во храмот св. Софија во Никеја ${ }^{20}$. Соборот успешно завршил, а во врска со одлуките, папата Адријан испратил писмо. Писмото започнува: „благочестивите господари и светли императори и победоносци, возљубените во Бога и Господ наш Исус Христос чеда, августејшим Константин и Ирина“21.

Во 782 година Ирина испратила барање до Карло Велики за да ја сврши неговата ќерка Ротруда за императорот Константин. Преговорите со Карло Велики биле прекинати од страна на Ирина во 788 година ${ }^{22}$.

Како против мерка на тоа, во 794 година Карло Велики го свикал Франкфуртскиот Собор ${ }^{23}$ и на него ја изнел идејата да стане „Римски император“. На Соборот Карло изјавил дека: никогаш жена не владеела со царскиот статус, уште повеќе, не претседавала на епископските Собори! „Немоќта на женскиот пол и непостојаноста на духот, се вели во канонските објаснувања на претензиите на Карло, не дозволуваат на жените да истапуваат со авторитет на учители, лесно склона кон грешки жената има потреба да биде раководена од маж. Во светите книги чи-

\footnotetext{
${ }^{18}$ Mansi, XII, 986D-990B; Карташов А. В., Васељенски Сабори, 529; Послание Адриана, святейшего папы древнего Рима к Константинопольскому патриарху Тарасию. „ДВС, , Т. 4, Спб. 1996, стр.482. Judith Herrin, Women in purple, 84-85; Успенски Ф., Историја византијског чарства. Т. 1, 704.

${ }^{19}$ Карташов А. В., Васељенски Сабори, 534; Judith Herrin, Women in purple, 86-87; Успенски Ф., Историја византијског иарства. Т. 1, 707.

${ }^{20}$ Mansi, XII, 991-1154, and XIII, 1-486; Judith Herrin, Women in purple, 88; Карташов А. В., Васељенски Сабори, 535, 537; Асмус Валентин, протоиерей, Седьмий Вселенский Собор 787 г., и власть императора в черкви, Regnum Aeternum. №1. Москва-Париж, 1996. 52.

21 «Благочестивейшим государям и светлейшим императорам и победоносцам, возлюбленнейшим в Бозе и Господе нашем Иисусе Христе чадам, августейшим Константину и Ирине» / «ДВС». Т.4. С.378, 379; Шафф Филип, История християнской Церкви. В 7 т, Т.4, СПб, 2008, стр. 152-153.

22 Феофан Византиец, Летопись от Диоклетиана до царей Михаила и сына его Феофилакma, стр. 390; Judith Herrin, Women in purple, 78-80; Успенски Ф., Историја византијског царства. Т. 1, 695.

${ }^{23}$ Успенски Ф., Историја византијског цүарства. Т. 1, 717.
} 
таме дека жената му е дадена на мажот за размножување на родот, за помош, но не е речено дека таа била назначена за учителство“224. Карло Велики ги прогласил Ирина и Константин за еретици и го натерал папата Адријан да го анатемиса VII Вселенски собор. На 25 декември 800 година, на Божиќ папата Лав III го крунисал Карло за император ${ }^{25}$, а веќе во есента 802 година во Константинопол пристигнало пратеништво од Карло за склучување на брак со Ирина ${ }^{26}$, но идејата не била реализирана ${ }^{27}$.

Ирина ги терала војниците да дадат заклетва: „нема да го признаеме царице, твојот син за цар додека си ти жива““28.

На 15 јули 797 година Константин VII бил уапсен по наредба на мајката и бил ослепен ${ }^{29}$. Од тогаш Ирина самостојно управува со империјата. На монетите наредила да стои натпис: „Ирина, велики римски василевс-автократор“30.

Друг пример кога жена управува во име на својот син е мајката на Михаил III - императорката Теодора. Теодора била Ерменка, родена во Пафлагонија. Таа била ретко убава жена и брачниот пар се сложувал. Така по раѓањето на четвртата ќерка Теофил наредил да се „искове златна монета“. На едната страна на монетата била претставена Теодора и најстарата ќерка Текла, на другата-ќерките Анастасија и Ана ${ }^{31}$. За византиската практика претставувањето на царското семејство од женски род било многу ретко, и токму по таа основа може да се суди за тоа, како се развивале односите во семејството на Теодора ${ }^{32}$.

Императорката имала големо влијание на својот сопруг. Царот ги уважувал родителите на својата жена. Мајка им Теоктиста била издигната во чин патриција и имала „право на слободен глас“"33.

${ }^{24}$ Успенский Ф. И., История Византийской империи. Т. 2, 421; Успенски Ф., Историја византијског иарства. Т. 1, 718.

${ }^{25}$ Острогорски Г., Историја Византије, 190; Judith Herrin, Women in purple, 121-122; Уcпенски Ф., Историја византијског иарства. Т. 1, 719.

${ }^{26}$ Theophanes, AM 6294, de Boor I, 475; RFA, a. 802, Lilie, Eirene und Konstantin VI, 210-212; Judith Herrin, Women in purple, 125.

${ }^{27}$ Величко А., История Византийских императоров, 3 том, стр. 115-116; Успенски Ф., Историја византијског цуарства. Т. 1, 731.

${ }^{28}$ Успенски Ф., Историја византијског ијарства. Т. 1, 696; История Византийских императоров, 3 том, стр. 116.

${ }^{29}$ Judith Herrin, Women in purple, 99.

${ }^{30}$ Величко А., История Византийских императоров, 3 том, 121; Карташов А. В., Васељенски Сабори, 547-548; Judith Herrin, Women in purple, 100.

${ }^{31}$ Judith Herrin, Women in purple, 191.

32 Афинганов Д. Е., Повесть о прощуении Феофила и Торжество Православия, Москва 2004, стр. 56; Величко А., История Византийских императоров, 3 том, стр. 291-292.

33 Продолжатель Феофана, Жизнеописание византийских чарей. Кн. III. Глава 5, Москва 1993, стр.63. 
По смртта на Теофило, како нејзини заштитници, назначени од Теофило биле: првиот министер на дворот - евнухот Теоктист, братот на царицата патрициј Варда и вујкото на Теодора магистер Мануил, сите Ерменци ${ }^{34}$.

Монасите им пришле на Теодора и ја замолиле да се заземе за Православието, а таа им одговорила дека веќе одамна мечтае само за тоа, но многу чиновници и епископи им попречуваат. Тогаш заштитниците (туторите) ја истакнале мислата дека како полноправна августа таа самата може да донесе решение: „само ти, госпоѓа, така пофално расудуваш и мислиш, што те спречува тебе да го доведеш сето тоа во исполнување и да ја направиш таа сенародна победа“호. Тогаш Теодора преку друнгарот на вигла патрициј Константин Ерменин, му испратила ултиматум на патријархот Јован Граматик, за да се повлече од службата и да заживее со монасите. На негово место бил избран Методиј (843-847) приврзаник на Православието.

Пролетта 843 година императорката свикала собор во Константинопол, за свечено да ја објави конечната победа над ереста. На денот на соборот царицата заедно со синот и синклитот, со свеќи во рака влегле во храмот, царевите пристапиле до патријархот и заедно пришле до олтарот, а оттука до царските двери. На заседанието царицата истапила со жесток говор. На крајот рекла: „Отци и клир Божји! Со голема благосклоност јас ви дарувам вам возобновување на светите икони!“. Потоа во првата недела на Великиот Пост, 11 март 843 година, отците од Соборот заедно со императорката одржале целоноќно пеење во храмот „св. Софија“" и свечено објавиле за воспоставување на иконопочитувањето ${ }^{36}$.

При изборот на нов патријарх, Игнатиј на 11 јули 847 година, главен збор имала императорката Теодора ${ }^{37}$.

Негде при крајот на владеењето на Теодора историските извори ни даваат податоци за уште една значајна жена, која што не е од владетелската фамилија, но била многу богата и е една од благодетелките на идниот византиски император Василиј I. Тоа била вдовицата Данилида, која што живеела на Пелопонез ${ }^{38}$. Таа кога разбрала за способностите на Василиј и за претскажувањата во врска со него, посакала да го запознае. При еден престој на Василиј заедно со императорот Михаил III на Пелопонез, Василиј се задржал во градот Патра и таму се запознал со Данилида и станале блиски пријатели. Кога Василиј сакал да се врати во Цариград Данилида го замолила да склучат духовно братство со нејзиниот син Јован, а во замена му дала 30 слуги, многу пари и му подарила на Македонецот големи зем-

${ }^{34}$ Карташов А. В., Васељенски Сабори, 569; История Византийских императоров, 3 том, 292; Успенски Ф., Историја византијског чуаства. Т. 1, 811.

${ }^{35}$ Продолжатель Феофана, Жизнеописание византийских иарей. Кн., 3 том, 293.

${ }^{36}$ Продолжатель Феофана, Жизнеописание византийских чарей. Кн. IV, глава 5 и 6, стр. 102 и 103; Карташов А. В., Васељенски Сабори, 571; Успенски Ф., Историја византијског чарства. Т. 1, 824.

${ }^{37}$ Успенски Ф., Историја византијског иарства. Т. 1, 833.

${ }^{38}$ Продолжатель Феофана, Жизнеописание византийских иарей. Кн. V. Гл.9, стр.148. 
јишни владенија. Така Василиј влегол во кругот на богатите луѓe во Византија, што му овозможило материјално да ги обезбеди мајка му и сестрите ${ }^{39}$.

Подоцна, кога Василиј станал цар, неговиот духовен брат бил прогласен за протоспатариј и добил право на слободен глас. Данилида дошла во Цариград и при средбата со царот му предала 500 слуги, евнуси, опширни работилници во Пелопонез и други богати дарови. Таа била удостоена со титулата „царска мајка“, по што Данилида се вратила на својот имот ${ }^{40}$.

Таа жена долго живеела и кога увидела дека животот се ближи до крај, таа уште еднаш се насочила кон престолнината, за да со свои очи да го види наследникот на императорот, неговиот син Лав, на кого што го оставила сиот нејзин имот, нејзиниот син Јован бил мртов. Доволно е да се каже дека покрај златото и 3000 подарени робови, Данилида му предала на царот 80 фабрики во негова лична сопственост $^{41}$. Средбата на Василиј со Данилида му го изменила животот, а нејзините постапки укажуваат на тоа дека таа самостојно одлучувала за нејзините богатства и располагала со имотот како што сакала.

Во периодот на владеењето на Македонската династија, забележана е политичката улога на Теофана-жената на Роман II. Роман II дошол на власт по смртта на татко му Константин VII (6 ноември 959 година) ${ }^{42}$. Заедно со Роман II на престолот дошла и неговата жена 18 годишната Теофана, која ја делела титулата августа со свекрвата Елена. Првин Роман бил женет за Берта, незаконородна ќерка на Хуго, но таа умрела. Потоа, Роман II се оженил со Анастасија, која што го зела името Теофана. Таа жена, не е понезначајна од Теодора. Теофана ги поразувала сите со својата убавина. Нејзиното потекло било непознато, се смета дека била ќерка на крчмарот Кротир, родум од Лакедемонија, кој што држел крчма во сиромашниот реон на Константинопол.

Роман се запознал со неа пред женидбата и меѓу нив се развила љубов. Татко му на Роман не сакал да се противи на чувствата на својот син, а идната снаа знаела како да ги маѓепса со својата убавина императорот и царицата Елена ${ }^{43}$. Во 958 година таа го родила синот Василиј, а во 960 и вториот син Константин. Потоа родила две ќерки Теофано и Ана ${ }^{44}$.

Авторитетот на царевите од Македонската династија бил толку висок што никој не смеел да се спротивстави на тој нерамноправен брак, иако новата царица народот не ја сакал. Тоа несакање прераснало во отворено нетрпение и на царицата ѝ се препишувале многу злодела. Се зборувало дека таа е виновна за смртта на Константин VII, кој што божем го отровила, што немало врска со реалноста.

${ }^{39}$ Исто, гл.11, стр. 149; История Византийских императоров, 4 том, стр. 10; Успенски Ф., Историја византијског чарства. Т. 2, Београд 2000, 13.

${ }^{40}$ Продолжатель Феофана, Жизнеописание византийских царей. Кн. V, глава 74 и 75, стр. 198 и 199.

${ }^{41}$ Величко А., История Византийских илператоров, 4 том, стр. 10.

42 Острогорски Г., Историја Византије, 272.

43 Дил Ш., Византийские портрети, стр. 148.

${ }^{44}$ Гиббон Э., Закат и падение Римской империи. Т. 3, Москва 2008, стр.365. 
Неоспорно е дека таа убава жена, честољубива и безжалосна, безпринципиелна и цинична, била спремна на секаков престап за да дојде до самостојна власт. Нејзиното влијание на мажот било апсолутно. Таа ги отстранила сите оние кои што можеле да имаат влијание на него. Само што станала царица, наредила сите сестри на царот да бидат замонашени. Истата судбина ја снашло и мајка му Елена ${ }^{45}$.

Два дена пред смртта на Роман II, Теофана ја родила ќерката Ана. Плашејќи се од конкурентки, дека друга жена може да им го преземе мажот, таа помислувала да го ликвидира и да остане самостојна владетелка. Пролетта 863 година Роман II тргнал на лов во шумата, но оттаму се вратил едвај дишејќи. Сите мислеле дека тоа е поради неумереното јавање. Почнале кај него да се појавуваат смртоносни грчеви, што за човек со спортски дух биле незамисливи. Мнозинството од граѓаните на Константинопол биле убедени дека на царот му дале да се напие отров пред да оди на лов, донесен од женскиот дел на дворецот, поточно од просториите на Теофана и ставен во пијалокот. Така или инаку, на 15 март 963 година Роман II умрел ${ }^{46}$, а поради малолетноста на неговите синови власта ја презела Теофана ${ }^{47}$. Воениот командант Никифор мислел дека за смртта на Роман се виновни неговите политички противници, пред сѐ Јосиф Вринги.

Набргу потоа војската го прогласила Никифор за император и тој влегол во Цариград. На 16 август 963 година Никифор II бил крунисан за император, при што дал ветување дека ќе ги штити малолетните императори. Набргу Никифор се вљубил во младата царица и стапил во брак со неа, 20 септември 963 година ${ }^{48}$.

Никифор ја испуштил од видот сопругата, која размислувала за подобра иднина за себе и за своите деца. Теофана решила да најде замена за Фока на царскиот престол. Пуштила гласини дека Никифор сака да ги ослепи Василиј и Константин и дека не сака да ја дели власта со нив. Притоа таа го задржала вниманието на Јован Цимиски и стапила со него во тајна преписка. Така Цимискиј станал последната љубов на Теофана. Заговорниците со помош на Теофана го убиле Никифор ноќта на 10 декември 969 година. Потоа војската за император го прогласила Јован Цимиски ${ }^{49}$.

Кога Цимиски сакал да биде крунисан од патријархот за цар, патријархот му поставил два услова. Прво да ги пронајде и казни убијците на Никифор и второ да ја протера Теофана од дворецот. Така завршила политичката кариера на Теофана.

Последни од низата владетели од Македонската династија се императорките Зоја (1042-1050) и Теодора $(1042-1056)^{50}$. Нивното заедничко владеење исто

${ }^{45}$ Продолжатель Феофана, Жизнеописание византийских иุарей. Кн. VI, глава 3, стр. 287; Острогорски Г., Историја Византије, 272.

${ }^{46}$ Величко А., История Византийских императоров, 4 том, 176.

${ }^{47}$ Острогорски Г., Историја Византије, 273.

${ }^{48}$ Исто, 273; Успенски Ф., Историја византијског царства. Т. 2, 377.

${ }^{49}$ Исто,279; История Византийских императоров, 4 том, 203; Успенски Ф., Историја византијског иарства. Т. 2, 402.

${ }^{50}$ История Византийских императоров, 4 том, 298-304; Успенски Ф., Историја византијског царства. Т. 2, 495. 
така покажува дека гласот на жените во византискиот двор се слушал и почитувал.

Наведените примери покажуваат дека жените во Византија не само што не молчеле туку тие наредуваат, командуваат со војската, одлучуваат за избор на патријарх и сл. Тоа се примери на жени од владетелските фамилии, за жал каква била состојбата со обичните жени, немаме доволно податоци. Како и да е, канонските одредби се спазувале само од обичните жени во присуство на нивните мажи во црква, но надвор од црквата гласот на жените се слушал и не може да се прифати дека тие биле осудени на молчење. 


\section{Литература}

Афинганов Д. Е., Повесть о прощении Феофила и Торжество Православия. Москва 2004.

Асмус Валентин, протоиерей, Седьмий Вселенский Собор 787 г., и власть императора в цееркви. Regnum Aeternum. №1. Москва-Париж, 1996.

Болотов В.В., История Церкви в период Вселенских Соборов. Москва 2007.

Бейкер Дж., Юстиниян. Великий законодател. Москва 2004.

Гиббон Э., Закат и падение Римской империи. Т. 3.Москва 2008.

Дил Ш., Юстиниян и византийская чивилизачия во VI век. Спб. 1909.

Дил Шарл, Византиске слике. 1-2. Београд 1929.

Жан-Клод Шене, Бернар Флизен, Византија -Историја и цивилизачија. CLIO, Београд 2010.

Величко А., История Византийских императоров. Том I-IV. Москва, 2012.

Judith Herrin, Women in purple. Weidenfeld \& Nicolson, London 2001.

Карташов А. В., Васељенски Сабори. Превод и поговор Мира Лалић, Београд 2009

Кулаковский Ю. А., История Византии. Т. 1. Санкт Петербург, 2003.

Лебедев А. П., Вселенские Соборы IV и V веков. Обзор их догматической деятельности в связи с направлениями школ Александрийской и Антиохийской. Спб. 2004.

Norič Dž. Dž., Vizantija rani vekovi. Beograd 2009.

Острогорски Г., Историја Византије. Београд 1969.

Остроумов М.А., Догматическое значение Седьмого Вселенского Сабора. Спб. 1884 Подбрани извори за историята на Византия. Под Редакция на Ангелов Д., София, 1956.

Послание Адриана, святейшего папы древнего Рима к Константинопольскому патриарху Тарасию. „ДВС, , Т. 4. Спб. 1996

Procopii Caesariensis, De bello Persikum. I. Lipsiae 1906.

Продолжатель Феофана, Жизнеописание византийских чарей. Кн.ІІІ. Москва 1993

Прокопий Кесарийский, Война с персами. Книга I .Москва 1993.

Свето Писмо (Библија). Скопје 1990

Успенски Ф. И., История Византийской империи. Т. 1 Москва,1948.

Успенски Ф., Историја византијског иарства. Т.1-3. Београд 2000.

Феофан Византиец, Летопись от Диоклетиана до иарей Михаила и сына его Феофилакта. Рязан, 2005.

Шафф Филип, История християнской Церкви. В 7 т, Т.4, СПб, 2008.

Шиканов В. Н., Византия - орел и лев. Болгаро-византийские войны VII-XIV вв. Спб. 2006. 


\section{SILENCE OF WOMEN IN BYZANTIUM BETWEEN THE CANONS LAW AND THE REALITY}

\section{Summary}

The subject of our research is the silence of women in the Middle Ages, with special emphasis of the silence of women in Byzantium, or more precisely - how in reality canonical provisions were respected by women and about provisions that women should remain silent in church at the front of man?

To be born as a man or women in any society is not just a simple biological fact. It is a biological fact that has social implications. Women constitute a special social group, and the character of that group, which historians have long ignored, has nothing in common with women's "nature". The problem lies in the nature of society and perception of women, so legal and historical sources speak about that from a special aspect - from a male worldview. Man had legal independence and the right to speak in public, but women were either prohibited or allowed with disapproval. Men possessed the power, and according to that, our sources mainly talk about them. It is particularly difficult to glance beneath the surface of the Middle Ages in order to realize the life of more modest members of the society. Therefore, our attention is focused to information about women from royal families, empresses; how much the provisions for silence were applicable for them and how some of them were engaged in discussions about certain religious issues, and their opinions led to important decisions which had a significant effect to the events in Byzantium. All of Byzantines which kept the data about their civilization (historians, lawyers or hagiographical compilers) were men and their writings are devoted to activities of their male fellows; that fact which make difficulties to our research, so we will refer to the provisions of the Byzantine legislation.

Keywords: WOMEN; LAWS; CANONS; EMPRESSES; RELIGIOUS DEBATES; SILENCE 